\title{
PENGEMBANGAN BAHAN AJAR MATEMATIKA BERBASIS VISUAL UNTUK PESERTA DIDIK TUNARUNGU
}

\author{
Kristina Weluk, Samuel Igo Leton, Meryani Lakapu \\ Universitas Katolik Widya Mandira Kupang, Jalan San Juan, Penfui Kupang \\ E-mail: meryanilakapu@unwira.ac.id
}

\begin{abstract}
Abstrak
Peserta didik yang memiliki berkebutuhan khusus juga mempunyai hak dalam memperoleh pendidikan sebagai bekal untuk kehidupannya, selayaknya peserta didik normal. Namun, sejumlah perangkat pembelajaran bagi mereka masih sangat sedikit. Hal ini dikarenakan sebahagian peneliti masih fokus kepada peserta didik normal. Oleh sebab itu, penelitian ini bertujuan untuk mengembangkan bahan ajar matematika berbasis visual pada materi operasi hitung bilangan bulat bagi mereka, salah satunya peserta didik tunarungu. Model pengembangan yang digunakan adalah model pengembangan yang dimodifikasi dari model 4D. Bahan ajar yang telah dikembangkan dan diujicobakan pada peserta didik tunarungu kelas VIII ini layak digunakan sebagai media pembelajaran dikarenakan memenuhi kriteria valid, praktis, dan efektif. Valid dikarenakan rata-rata nilai dari ketiga validator adalah 3,85. Selanjutnya, kriteria praktis dikarenakan persentase rataan skor respons peserta didik yang diperoleh adalah $80 \%$. Terakhir, kriteria efektif disebabkan rata-rata nilai peserta didik yang mencoba menyelesaikan soal tes tersebut adalah 81 . Hasil penelitian ini berkontribusi dalam memberikan alternatif bahan ajar bagi siswa tunarungu.
\end{abstract}

Kata Kunci: Pengembangan, Bahan Ajar, Visual, Peserta Didik Tunarungu

\begin{abstract}
Students who have special needs also have the right to obtain an education as a provision for life, just like regular students. However, several learning tools for them are still very few. It is because some researchers always focus on standard students. Therefore, this study aims to develop visualbased mathematics teaching materials on integer arithmetic operations, one of which is deaf students. The development model used is a modified development model from the 4D model. Teaching materials that have been developed and tested on deaf class VIII students are suitable for use as a learning medium because they meet the criteria of being valid, practical, and effective. Valid because the average value of the three validators is 3.85 . Furthermore, the practical standard is because the percentage of the average response score of students obtained is $80 \%$. Finally, the effective criterion is that the average score of students trying to solve the test questions is 81 . The results of this study contribute to providing alternative teaching materials for deaf students.
\end{abstract}

Keywords: Development, Teaching Materials, Visual, Deaf Students

\section{PENDAHULUAN}

Anak berkebutuhan khusus adalah anak yang memiliki karakter dan kebutuhan berbeda dalam hal interaksi dan perlakuan (Jannah \& Prahmana, 2019; Nuari \& 
Prahmana, 2019). Istilah yang sering digunakan untuk kelompok ini adalah disabilitas. Anak disabilitas oleh peneliti di bidang Anak Berkebutuhan Khusus (ABK) dinyatakan sebagai anak berkebutuhan khusus. ABK tidak mampu melakukan sesuatu seperti orang normal, tetapi mereka melakukannya dengan cara yang berbeda (Maftuhin, 2016). Mereka memiliki beberapa jenis ketunaan berdasarkan fisik dan juga mental. Jika dikaitkan dalam dunia pendidikan, tunarungu termasuk peserta didik kelas $\mathrm{B}$, peserta didik yang memiliki keterbatasan atau ketidakmampuan dalam berkomunikasi secara lisan, sehingga mereka mengutamakan komunikasi tulisan dan isyarat. Sebagai akibatnya, mereka hanya mengandalkan indra penglihatan sebagai alat komunukasi.

Peserta didik tunarungu merupakan peserta didik yang mengalami gangguan fungsi pendengaran baik sebagian maupun seluruhnya yang berdampak kompleks dalam kehidupannya (Leton, Lakapu \& Dosinaeng, 2019). Pemerintah Indonesia dalam hal ini Kementerian Pendidikan, telah memberikan dukungan terhadap Anak Berkebutuhan Khusus untuk bisa memperoleh pendidikan. Peraturan Pemerintah RI nomor 71 tahun 1991, tentang Pendidikan Luar Biasa (PLB). Kemudian dikembangkan dengan peraturan tentang Ujian Nasional untuk peserta didik berkebutuhan khusus. Ini tertuang dalam Keputusan Presiden nomor 77 tahun 2007 tentang Peraturan Menteri Pendidikan Nasional Republik Indonesia nomor 70 tahun 2009 tentang Pendidikan Inklusif (PENSIF) Bagi Peserta Didik Yang Memiliki Kelainan dan Memiliki Potensi Kecerdasan dan/atau Bakat Istimewa.

Pendidikan memiliki kaitan erat dengan lembaga-lembaga pendidikan, terutama sekolah. Terdapat sejumlah mata pelajaran yang merupakan pelajaran wajib dan pelajaran pendukung di sekolah. Salah satu pelajaran yang wajib diajarkan adalah matematika (Tanujaya, Prahmana \& Mumu, 2017). Lebih lanjut, peserta didik yang mengalami gangguan pendengaran (tunarungu) juga memperoleh mata pelajaran matematika melalui jalur pendidikan khusus. Lembaga pendididikan bagi ABK adalah Sekolah Dasar Luar Biasa (SDLB), Sekolah Menengah Pertama Luar Biasa (SMPLB) dan Sekolah Menengah Atas Luar Biasa (SMALB) (Leton, 2018).

Dalam rangka untuk menunjang keberhasilan, pembelajaran matematika pada peserta didik di Sekolah Luar Biasa (SLB) membutuhkan sarana dan prasarana pokok atau penunjang (Kamaruddin, 2019). Hal ini dikarenakan berbagai keterbatasan peserta didik tunarungu, meliputi kondisi fisik, mental, emosi, dan sosial. Peserta didik SLB 
membutuhkan pendidikan dan pelayanan khusus dari guru.

Para guru SLB dituntut untuk berkreasi mengembangkan strategi atau metode dalam upaya memberikan pendidikan yang terbaik untuk peserta didik (Suningsih \& Arnidha, 2017). Lingkungan pendidikan bagi peserta didik SLB lebih bervariasi jika dibandingkan dengan pendidikan pada peserta didik formal, maka pemilihan strategi, metode pendekatan dalam pembelajaran harus mempertimbangkan kondisi pesrta didik. Guru SLB dituntut untuk lebih berperan aktif dalam menyampaikan informasi matematika kepada peserta didik. Guru harus berusaha keras untuk mengembangkan komunikasi dan mengelola pembelajaran sesuai dengan karakteristik anak tunarungu. Keberhasilan pembelajaran sangat dipengaruhi oleh berbagai hal, diantaranya adalah pemilihan bahan ajar. Materi-materi tersebut perlu disajikan dalam bahan ajar khusus untuk pembelajaran matematika bagi peserta didik tunarungu (Syafrudin \& Sujarwo, 2019).

Bahan ajar matematika sangat dibutuhkan peserta didik tunarungu dalam proses pembelajaran. Bahan ajar berupa media visual berfungsi menyalurkan pesan dari sumber kepada penerima pesan. Kemampuan visual yang dimiliki sangat bermanfaat bagi peserta didik tunarungu dalam proses pembelajaran. Mereka menggunakan ketajaman visual yang merupakan kekuatannya dalam proses pembelajaran untuk meningkatkan perkembangan bahasa dan komunikasi (Leton, Wahyudin \& Darhim, 2018).

Penggunaan bahan ajar berbasis visual dapat membantu peserta didik tunarungu dalam mengenal bentuk benda melalui bentuk gambar yang disajikan. Gambar yang disajikan dalam pembelajaran dapat melatih peserta didik untuk menganalisis dan menyimpulkan sehingga mereka dapat memahami materi yang disampaikan dalam pembelajaran matematika (Syafrudin \& Sujarwo, 2019). Namun demikian, bahan ajar visual yang secara khusus diperuntukan bagi siswa berkebutuhan khusus, seperti tuna rungu tidak tersedia. Dilain pihak, bahan ajar visual bagi ABK bersifat spesifik dan kontekstual. Oleh karena itu, perlu adanya pengembangan bahan ajar berbasis visual yang tujuannya untuk membantu ABK dalam memahami materi yang akan diajarkan.

Bahan ajar yang berkualitas baik merupakan perangkat pembelajaran yang dapat digunakan peserta didik dalam pembelajaran sehingga tujuan pembelajaran dapat dicapai (Lakapu et al, 2020). Pengembangan perangkat pembelajaran matematika pernah juga dilakukan bagi peserta didik tidak berkebutuhan khusus (Mahmudah, Ahyan \& Rasidi , 
2018).

Berdasarkan uraian diatas, anak berkebutuhan khusus pada umumnya wajib memperoleh pendidikan sebagai bekal untuk kehidupannya. Salah satu upaya yang dapat dilakukan adalah menyediakan bahan ajar yang dapat membantu siswa berkebutuhan khusus dalam pembelajaran. Oleh karena itu, perlu dilakukan penelitian untuk mengembangkan bahan ajar berbasis visual bagi siswa Tuna Rungu.

\section{METODE PENELITIAN}

Penelitian ini adalah penelitian pengembangan yang bertujuan untuk menghasilkan bahan ajar bagi siswa tunarungu. Model pengembangan yang digunakan adalah model pengembangan yang dimodifikasi dari model yang dikembangkan oleh S. Thagarajan, Dorothy S. Sammel dan Melvyn I. Sammel yakni four-D.

Prosedur penelitian dan pengembangan bahan ajar matematika tunarungu ini terdiri dari empat tahap yakni:

1. Tahap pendefinisian (define), terdiri dari analisis awal-akhir, analisis siswa, analisis tugas, analisis konsep dan analisis perumusan tujuan;

2. Tahap perancangan (design), terdiri dari pemilihan media, pemilihan format dan rancangan awal;

3. Tahap pengembangan (develop), pada tahap ini akan dilakukan ujicoba secara terbatas untuk melihat kevalidan, kepraktisan dan keefektifan dari perangkat yang dikembangkan.

4. Tahap penyebaran (Disseminate), pada tahap ini bahan ajar yang dikembangkan kemudian dapat distribusikan untuk digunakan dalam pembelajaran.

Pada tahap pengembangan, syarat cukup agar suatu perangkat pembelajaran apabila memenuhi tiga kriteria, yaitu valid, praktis dan efektif (Sudijono, 2011). Penilaian validitas bahan ajar dilakukan oleh pakar, dengan mengacu pada instrumen penilaian menggunakan skala Likert, dengan melakukan penilaian terhadap 20 indikator sebagai aspek penilaian, sebagai mana disajikan pada Tabel 1. Bahan ajar yang dikembangkan dinyatakan valid jika skor rata-rata total validasi ahli minimal 2 atau minimal berkategori cukup valid. 
Tabel 1. Instrumen penilaian validitas Bahan ajar menggunakan skala Likert

\begin{tabular}{rllll}
\hline \multirow{2}{*}{ No } & \multicolumn{1}{c}{ Aspek yang Dinilai } & \multicolumn{3}{c}{ Nilai } \\
\cline { 3 - 4 } 2 & \multicolumn{1}{c}{1} & 2 & 3 & 5 \\
\hline 1 & Kesesuaian dengan Kompetensi Dasar dan Tujuan & & & \\
3 & Pebenaran materi pembelajaran & & \\
4 & Kesesuaian materi \\
5 & Manfaat untuk menambah wawasan \\
6 & Keterbacaan \\
7 & Kejelasan informasi \\
8 & Kesesuaian dengan kaidah bahasa Indonesia (EYD) \\
9 & Bahasa dalam bahan ajar sesuai dengan tahap \\
& perkembangan bahan ajar \\
10 & Penggunaan bahasa efektif dan efisien \\
11 & Kejelasan tujuan yang ingin dicapai \\
12 & Petunjuk penggunaan bahan ajar mudah dipelajari \\
13 & Urutan sajian \\
14 & Pemberian motivasi dan daya tarik \\
15 & Interaksi (pemberian stimulus dan respon) \\
16 & Gambar yang disajikan berhubungan/mendukung \\
& kejelasan materi \\
\hline 19 & Kelengkapan informasi \\
\end{tabular}

Dimana,

$1=$ Sangat tidak sesuai

$2=$ Kurang sesuai

$3=$ Cukup

$4=$ Sesuai

$5=$ Sangat sesuai 
Selanjutnya, Tabel 2. digunakan untuk menentukan validitas bahasa ajar, hasil penilaian yang dilakukan oleh pakar.

Tabel 2. Kriteria Validitas Bahan Ajar

\begin{tabular}{clc}
\hline No & \multicolumn{1}{c}{ Kategori } & Skor \\
\hline 1 & Sangat Valid & $4,3-5$ \\
2 & Valid & $3,5-4,2$ \\
3 & Cukup Valid & $2,7-3,4$ \\
4 & Kurang Valid & $1,9-2,6$ \\
5 & Tidak Valid & $0-1,8$ \\
\hline
\end{tabular}

Bahan ajar yang dikembangkan, dinyatakan praktis jika persentase rata-rata skor minimal $65 \%$ atau minimal berkategori cukup praktis. Kriteria untuk menentukan kepraktisan suatu bahan ajar yang dikembangkan dilakukan dengan berpedoman pada Tabel 3. Terakhir, bahan ajar yang dikembangkan efektif, jika nilai rata-rata hasil belajar peserta didik minimal 75.

Tabel 3. Kategori Kepraktisan Bahan Ajar

\begin{tabular}{cll}
\hline No & \multicolumn{1}{c}{ Kategori } & Skor $(\%)$ \\
\hline 1 & Sangat Praktis & $90-100$ \\
2 & Praktis & $80-89$ \\
3 & Cukup Praktis & $65-79$ \\
4 & Kurang Praktis & $55-64$ \\
5 & Tidak Praktis & $0-54$ \\
\hline
\end{tabular}

\section{HASIL DAN PEMBAHASAN}

\section{Tahap Pendefinisian}

Penelitian ini diawali dengan kegiatan observasi untuk mendeskripsikan hasil analisis pada tahap ini, yakni analisis awal-akhir, analisis siswa, analisis tugas, analisis konsep dan analisis perumusan tujuan. Berikut ini adalah hasil analisis pada tahap pendefinisian:

1. Analisis Awal-Akhir

Analisis kebutuhan ini mengacu pada kondisi di lapangan (Sekolah Luar Biasa). 
Analisis dilakukan untuk mengetahui apakah bahan ajar perlu dikembangkan atau tidak. Analisis kebutuhan dilakukan dengan beberapa tahap, yaitu observasi kegiatan pembelajaran, wawancara guru matematika dan observasi perangkat pembelajaran. Berdasarkan hasil wawancara dan observasi yang dilakukan, diperoleh informasi bahwa pada proses belajar mengajar, guru menggunakan bahan ajar berupa buku matematika untuk sekolah umum tetapi ada adaptasi pembelajaran sesuai dengan kemampuan peserta didik, karena pada sekolah tersebut belum memiliki buku matematika khusus untuk anakanak berkebutuhan khusus.

\section{Analisis Peserta Didik}

Berdasarkan observasi di lapangan, peserta didik tunarungu pada sekolah tersebut merupakan peserta didik tunarungu murni, dalam hal ini mereka yang kehilangan kemampuan pendengaran secara total. Selain mengalami kelainan pada indera pendengaran, mereka juga mengalami gangguan bicara. Hal ini disebabkan karena terbatasnya informasi (konsep kata dan kalimat) yang direkam oleh otak mereka, sehingga mereka kesulitan dalam merekam dan mengutarakan kembali kata-kata dan kalimat-kalimat tersebut. Komunikasi yang digunakan berupa bahasa isyarat tradisonal (yang biasa digunakan sehari-hari, bukan bahasa isyarat murni tunawicara yang melalui pembelajaran isyarat sebenarnya) sehingga perkembangan intelektual, keterampilan peserta didik pada sekolah tersebut juga mengalami hambatan.

\section{Analisis Tugas}

Tugas-tugas yang diberikan kepada peserta didik antara lain: melakukan operasi hitung bilangan bulat yang meliputi penjumlahan dan pengurangan bilangan bulat.

4. Analisis Konsep

Wawancara yang dilakukan pada analisis ini adalah untuk mengidentifikasi materi yang diajarkan. Materi yang diajarkan di sekolah tersebut disesuaikan dengan kebutuhan peserta didik. Struktur isi pada materi ini adalah:

1). Fakta:

a. Masalah kontekstual yang berkaitan dengan penggunaan bilangan bulat seperti temperatur atau suhu berbagai benda,

b. Masalah kontekstual yang berkaitan dengan penggunaan bilangan pecahan,

c. Garis bilangan. 
2).Konsep:

a. Pengertian bilangan bulat,

b. Jenis bilangan bulat.

3).Prinsip:

a. Berdasarkan letak bilangan bulat pada garis bilangan, maka:

- Dikatakan $a<b$, jika $a$ posisinya terletak disebelah kiri $b$ atau $b$ berada disebelah kanan $a$

- Dikatakan $a>b$, jika $a$ posisinya terletak disebelah kanan $b$ atau $b$ berada disebelah kiri $a$

b. Jika $a$ dan $b$ bilangan bulat dengan $b \neq 0$, maka $\frac{a}{b}$ merupakan bilangan pecahan dengan a tidak habis membagi $\mathrm{b}$, maka $a$ disebut pembilang dan $b$ disebut penyebut

4).Prosedur:

a. Langkah-langkah membuat garis bilangan,

b. Langkah-langkah membandingkan bilangan bulat,

c. Langkah-langkah mengoperasikan bilangan bulat.

5. Perumusan Tujuan Pembelajaran

Adapun tujuan pembelajaran yang ingin dicapai setelah mempelajari materi ini, peserta didik diharapkan mampu:

1). Membaca dan menulis bilangan bulat

2). Memahami bilangan bulat negatif

3). Memahami bilangan bulat positif

4). Mengoperasikan bilangan bulat positif dengan bilangan bulat negatif

\section{Tahap Perancangan}

Pada ini dilakukan pemilihan media, pemilihan format dan rancangan awal. Berikut ini adalah hasil analisis pada tahap perancangan.

1. Pemilihan Media

Media pembelajaran yang dipilih adalah bahan ajar berbasis visual. Bahan ajar ini dipilih untuk digunakan karena dapat mempermudah peserta didik tunarungu dalam 
proses pembelajaran. Pemilihan media ini disesuaikan dengan analisis tugas, analisis konsep dan fasilitas yang terdapat di sekolah dan selanjutnya divalidasi dan diujicobakan pada tahap pengembangan. Media yang digunakan adalah media grafis. Media grafis sendiri merupakan media visual yang menyajikan fakta, ide atau gagasan melalui penyajian kata-kata, kalimat atau angka-angka dan simbol/gambar.

\section{Pemilihan Format}

Menyesuaikan Kompetensi Inti, Kompetensi Dasar dan silabus berdasarkan Kurukulum 2013 adalah langkah-langkah dalam pengerjaan desain produk ini. Bahan ajar ini menggunakan kertas A4, skala spasi 1.5, jenis huruf Comic Sans Ms, Algerian. Format Bahan Ajar meliputi: Mata pelajaran, kelas/semester, tahun pelajaran, kompetensi dasar, materi pembelajaran, kegiatan pembelajaran

\section{Rancangan Awal}

Rancangan awal bahan ajar ini adalah: cover depan, skema materi (KD dan Tujuan Pembelajaran), Peta Konsep, materi penjumlahan dan pengurangan, contoh soal, rangkuman dan evaluasi. Berikut ini adalah hasil rancangan awal bahan ajar berbasis visual, sebagaimana disajikan pada Gambar 1 dan Gambar 2.
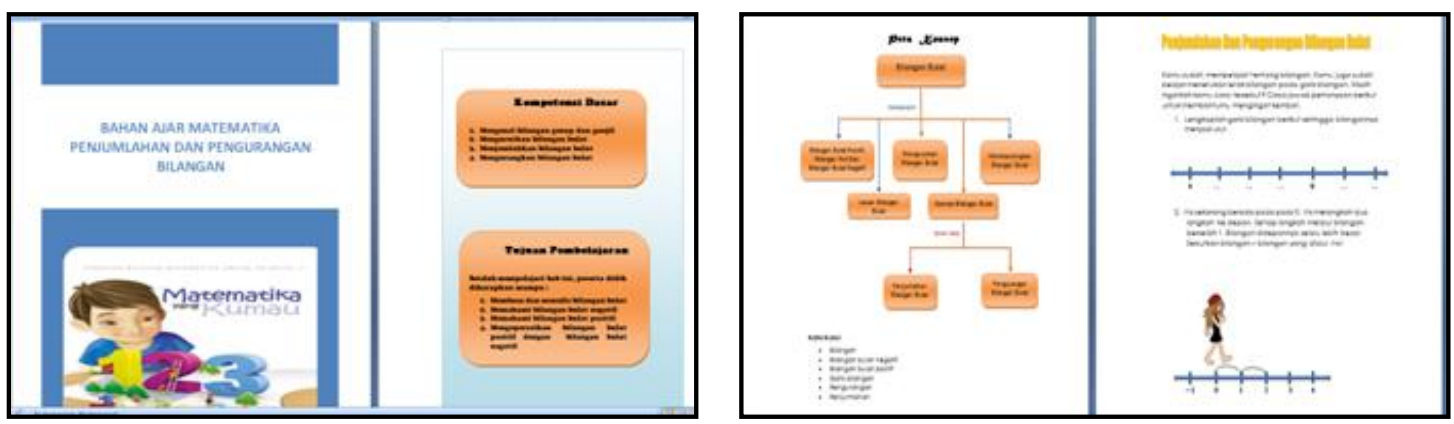

Gambar 1. Rancangan Bahan Ajar Berbasis Visual untuk Halaman 1 dan 4
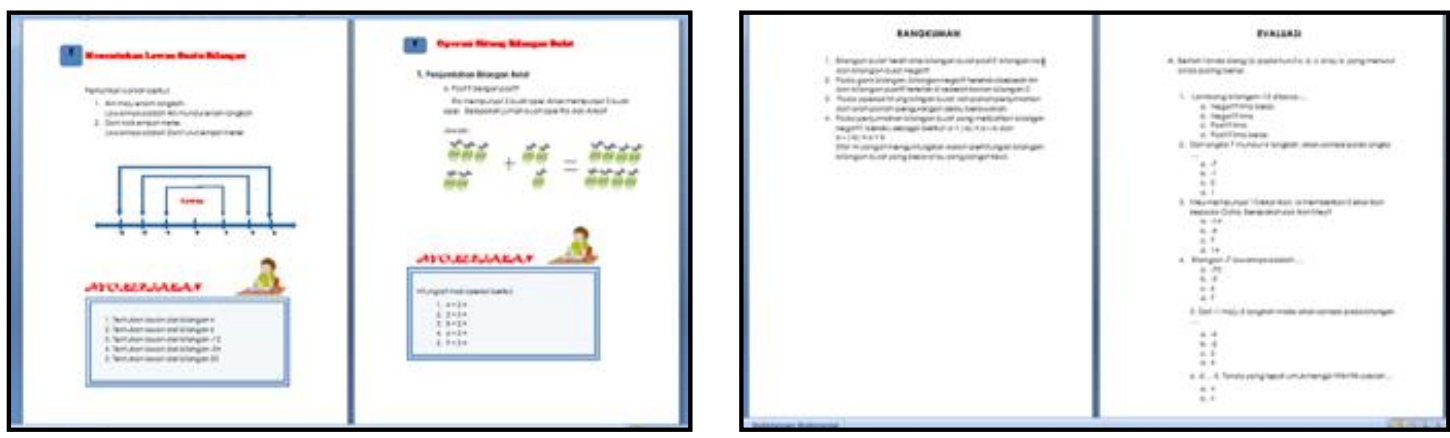

Gambar 2. Ranncangan Bahan Ajar Berbasis Visual untuk Halaman 9, 10, 15 dan 16 


\section{Tahap pengembangan}

Pada tahap ini dilakukan ujicoba secara terbatas untuk melihat kevalidan, kepraktisan dan keefektifan dari perangkat (bahan ajar) yang dikembangkan. Berikut ini adalah hasil analisis pada tahap pengembangan:

1. Validasi

Bahan ajar yang sudah didesain selanjutnya divalidasi oleh 3 validator terdiri dari 2 dosen pendidikan matematika serta 1 orang guru matematika pada Sekolah Luar Biasa Kota Kupang. Tujuan validasi ahli yaitu untuk mengetahui kesesuaian materi, kebenaran bahasa dan urutan materi.

2. Revisi Produk

Saran atau komentar mengenai bahan ajar matematika berbasis visual untuk peserta didik tunarungu tersebut digunakan peneliti sebagai petunjuk untuk merevisi bahan ajar yang dikembangkan. Berikut ini adalah hasil validasi dari 3 orang ahli, sebagaimana disajikan pada Tabel 4.

Tabel 4. Hasil Validasi Pakar terhadap Rancangan Bahan Ajar berbasis Visual

\begin{tabular}{|c|c|c|c|c|c|}
\hline \multirow{2}{*}{ No } & \multirow{2}{*}{ Aspek Yang Dinilai } & \multicolumn{3}{|c|}{ Validator } & \multirow{2}{*}{$\begin{array}{l}\text { Rata- } \\
\text { rata }\end{array}$} \\
\hline & & 1 & 2 & 3 & \\
\hline 1 & $\begin{array}{l}\text { Kesesuaian dengan Kompetensi Dasar dan } \\
\text { Tujuan }\end{array}$ & 4 & 4 & 4 & 4 \\
\hline 2 & Kebenaran materi pembelajaran & 4 & 4 & 4 & 4 \\
\hline 3 & Penggunaan contoh yang sesuai & 3 & 4 & 4 & 3.6 \\
\hline 4 & Kesesuaian materi & 4 & 4 & 5 & 4.3 \\
\hline 5 & Manfaat untuk menambah wawasan & 4 & 4 & 4 & 4 \\
\hline 6 & Keterbacaan & 4 & 4 & 4 & 4 \\
\hline 7 & Kejelasan informasi & 3 & 3 & 4 & 3.3 \\
\hline 8 & $\begin{array}{l}\text { Kesesuaian dengan kaidah bahasa Indonesia } \\
\text { yang baik dan benar (EYD) }\end{array}$ & 4 & 4 & 4 & 4 \\
\hline 9 & $\begin{array}{l}\text { Bahasa dalam bahan ajar sesuai dengan tahap } \\
\text { perkembangan bahan ajar }\end{array}$ & 4 & 4 & 3 & 3.7 \\
\hline 10 & Penggunaan bahasa efektif dan efisien & 4 & 4 & 4 & 4 \\
\hline 11 & Kejelasan tujuan yang ingin dicapai & 4 & 5 & 4 & 4.3 \\
\hline
\end{tabular}




\begin{tabular}{|c|c|c|c|c|c|}
\hline \multirow{2}{*}{ No } & \multirow{2}{*}{ Aspek Yang Dinilai } & \multicolumn{3}{|c|}{ Validator } & \multirow{2}{*}{$\begin{array}{r}\text { Rata- } \\
\text { rata }\end{array}$} \\
\hline & & 1 & 2 & 3 & \\
\hline 12 & $\begin{array}{l}\text { Petunjuk penggunaan bahan ajar mudah } \\
\text { dipelajari }\end{array}$ & 4 & 3 & 3 & 3.3 \\
\hline 13 & Urutan sajian & 4 & 3 & 4 & 3.7 \\
\hline 14 & Pemberian motivasi dan daya tarik & 3 & 4 & 4 & 3.7 \\
\hline 15 & Interaksi (pemberian stimulus dan respon) & 3 & 3 & 4 & 3.3 \\
\hline 16 & $\begin{array}{l}\text { Gambar yang disajikan } \\
\text { berhubungan,mendukung kejelasan materi }\end{array}$ & 3 & 4 & 4 & 3.7 \\
\hline 17 & Kelengkapan informasi & 4 & 4 & 4 & 4 \\
\hline 18 & Penggunaan jenis dan ukuran huruf & 4 & 4 & 4 & 4 \\
\hline 19 & Tata letak & 3 & 4 & 5 & 4 \\
\hline 20 & Ilustrasi atau gambar & 3 & 4 & 5 & 4 \\
\hline & Rata-Rata & & & & 3.85 \\
\hline
\end{tabular}

Berdasarkan rata-rata pada Tabel 4., dan sesuai dengan kriteria pada Tabel 2, maka bahan ajar yang dikembangkan berkategori "valid". Kenyataan ini menginformasikan bahwa bahan ajar tersebut baik atau layak untuk diuji coba, setelah dilakukan beberapa koreksi berdasarkan saran dari para Validator. Berikut ini adalah beberapa saran dari validator

1. Perlu menambahkan keterangan "bilangan nol" pada bagian "mengenal bilangan bulat positif, bilangan nol dan bilangan bulat negatif, seperti penjelasan pada Tabel 5.

Tabel 5. Perbandingan Bagian Bahan Ajar pada Kasus Pertama

A Mengenal Bilangan Bulat Positif, Bilangan Nol, dan Bilangan Bulat Negatif

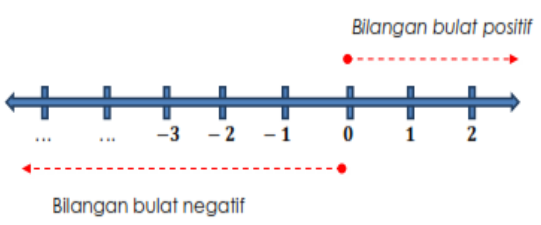

Mengenal Bilangan Bulat Positif, Bilangan Nol, dan Bilangan Bulat Negatif

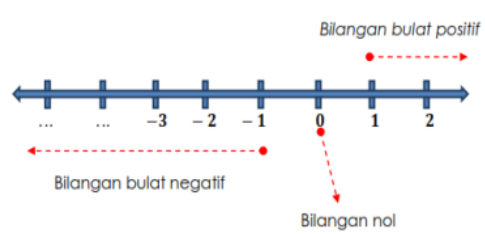


2. Perlu menggantikan tanda $(+)$ dan $(=)$ pada bagian "penjumlahan bilangan bulat" dengan kata "digabung" dan kata "hasilnya", seperti yang dirangkum pada Tabel 6.

Tabel 6. Perbandingan Bagian Bahan Ajar pada Kasus Kedua

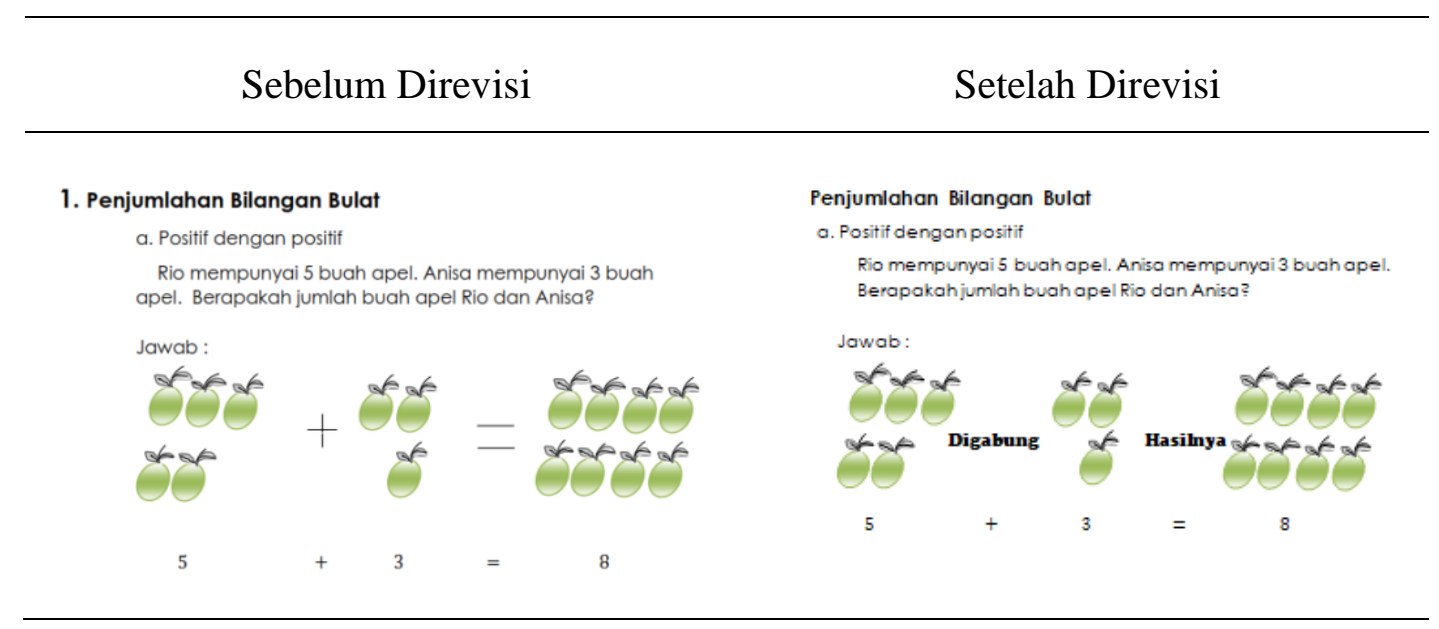

3. Pada bagian "penjumlahan bilangan bulat, negatif dengan negatif”, disarankan untuk mengubah gambar agar sesuai dengan keterangannya, seperti tampak pada Tabel 7.

Tabel 7. Perbandingan Bagian Bahan Ajar pada Kasus Ketiga

\begin{tabular}{|c|c|}
\hline Sebelum Direvisi & Setelah Direvisi \\
\hline 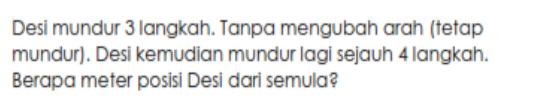 & 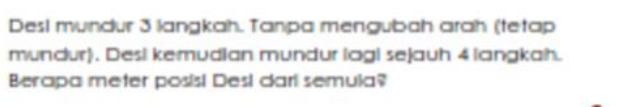 \\
\hline $\begin{array}{llllllllll}-7 & -6 & -5 & -4 & -3 & -2 & -1 & 0\end{array}$ & $\begin{array}{lllllllllll}-7 & -6 & -5 & -4 & -3 & -2 & -1 & 0\end{array}$ \\
\hline
\end{tabular}

Setelah melakukan koreksi sesuai dengan saran validator, maka peneliti kemudian melakukan uji coba produk untuk mengukur kepraktisan dan keefektifan dari produk yang telah dikembangkan. Praktis atau tidaknya bahan ajar yang telah dikembangkan dilihat dari respons peserta didik terhadap bahan ajar. Berikut ini adalah pernyataanpernyataan yang menjadi indikator penilaian adalah gaya penyajian bahan ini 
membosankan, terdapat kata atau kalimat yang tidak saya pahami, tugas-tugas atau latihan-latihan dalam bahan ajar ini terlalu sulit, tidak ada materi dalam bahan ajar ini yang saya pahami, dan isi bahan ajar ini sangat bermanfaat bagi saya. Persentase rataan skor yang diperoleh adalah $80 \%$, yang artinya bahan ajar yang dikembangkan berkategori "praktis". Hal ini berarti bahwa bahan ajar yang dikembangkan mudah dipahami oleh peserta didik.

Berikut ini adalah salah satu hasil kerja siswa untuk tiga nomor soal yang diberikan. Gambar 3 menjelaskan bahwa peserta didik yang bersangkutan tidak mengalami kesulitan dalam mengurutkan bilangan dan menyelesaikan soal cerita yang berkaitan dengan operasi pengurangan bilangan bulat secara langsung, tetapi peserta didik tersebut salah dalam mengoperasikan bilangan bulat menggunakan garis bilangan.

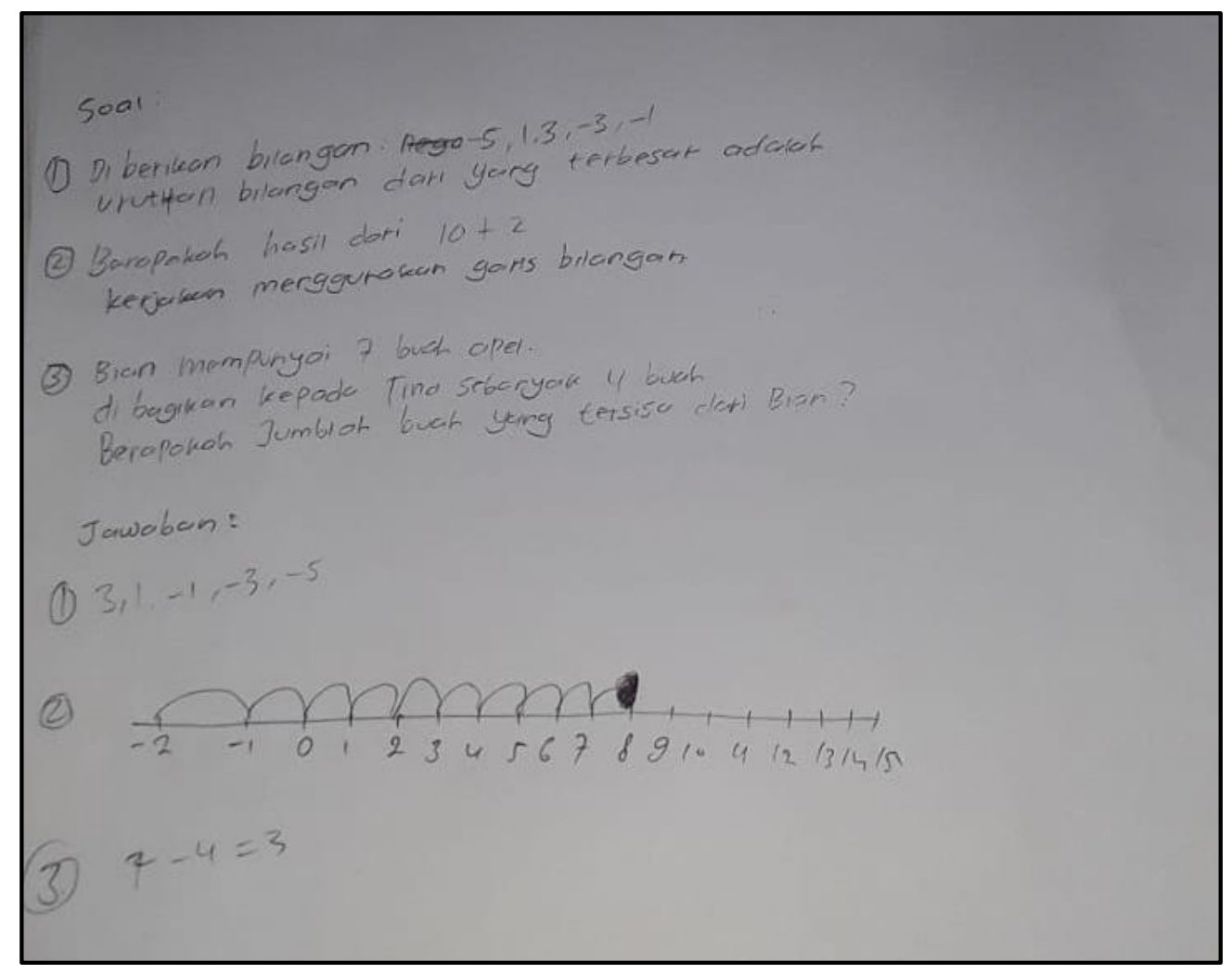

Gambar 3. Contoh Hasil Kerja Peserta Didik

Hal ini disebabkan karena peserta didik tersebut sudah terbiasa dengan mencacah menggunakan jari, sehingga ketika diajarkan menggunakan cara yang baru (dalam waktu yang singkat), peserta didik tersebut tidak secara maksimal memahami konsep tersebut. Rata-rata nilai peserta didik yang mencoba menyelesaikan soal tes tersebut adalah sebesar 
81. Nilai yang diperoleh tersebut menunjukkan bahwa bahan ajar yang dikembangkan, memenuhi kriteria efektif (Sudijono, 2011).

\section{KESIMPULAN}

Bahan ajar matematika berbasis visual materi operasi hitung bilangan bulat yang dikembangkan dan diujicobakan pada peserta didik tunarungu kelas VIII ini layak digunakan sebagai media pembelajaran karena memenuhi kriteria valid, praktis dan efektif. Hal ini dikarenakan hasil penelitian menujukkan bahan ajar yang dikembangkan seluruh indikator valid $(3,85)$, praktis $(80 \%)$, dan efektif $(81)$.

\section{DAFTAR PUSTAKA}

Jannah, A. F., \& Prahmana, R. C. I. (2019). Learning Fraction using the Context of Pipettes for Seventh-Grade Deaf-Mute Student. Journal for the Education of Gifted Young Scientists, 7(2), 299-321.

Kamaruddin, K. (2019). Bimbingan Karir Terhadap Anak Tuna Netra di Sekolah Luar Biasa Negeri Pinrang. Indonesian Journal of Islamic Counseling, 1(1), 56-76.

Lakapu, M., Fernandez, A. J., Djong, K. D., Fernandez, M., Gawa, M. G. M. (2020). Pengembangan Bahan Ajar Berbasis Etnomatematika Materi Persamaan dan Pertidaksamaan Linear Satu Variabel. Figma Jurnal Pendidikan, 4(1), 50-55.

Leton, S. I. (2018). Kemampuan Koneksi dan Pemecahan Masalah Matematis serta Kegemaran Belajar Matematika Siswa Tunarungu Kelas VIII. Bandung: Tesis UPI.

Leton, S. I., Lakapu, M., \& Dosinaeng, W. B. N. (2019). Kemampuan Pemecahan Masalah Matematis pada Siswa Tunarungu dalam Menyelesaikan Masalah Non Rutin. Math Didactic: Jurnal Pendidikan Matematika, 5(2), 157-167.

Leton, S. I., Wahyudin, \& Darhim (2018). Mathematical Connection Ability of Deaf Student in Completing. Journal of Physics: Conference Series, 1280(4), 042012.

Maftuhin, A. (2016) Mengikat Makna Diskriminasi: Penyandang Cacat, difabel, dan Penyandang Disabilitas. INKLUSI: Journal of Disability Studies, 3(2), 139-162.

Mahmudah, R., Ahyan, S., \& Rasidi, A. (2018). Pengembangan Media Pembelajaran Matematika dengan menggunakan Software Lectora Inspire pada Materi Perbandingan untuk Siswa Kelas VII SMP. Journal of Honai Math, 1(1), 47-55.

Nuari, L. F., \& Prahmana, R. C. I. (2019). The ability of seventh-grade disabilities students in solving number operation problems. Journal of Physics: Conference Series, $1188(1), 012015$.

Sudijono. (2011). Evaluasi Pendidikan. Jakarta: Raja Grafindo Persada. 
Suningsih, A., \& Arnidha, Y. (2017). Komunikasi Matematis Siswa Tunarungu melalui Model Pembelajaran Think Pair Share. Aksioma: Jurnal Program Studi Pendidikan Matematika, 6(3), 375-384.

Syafrudin, T., \& Sujarwo, S. (2019). Pengembangan Bahan Ajar untuk Pembelajaran Matematika bagi Siswa Tunarungu. Suska Journal of Mathematics Education, 5(2), 87-94.

Tanujaya, B., Prahmana, R. C. I., \& Mumu, J. (2017). Mathematics Instruction, Problems, Challenges, and Opportunities: A Case Study in Manokwari Regency, Indonesia. World Transactions on Engineering and Technology Education, 15(3), 287-291. 
Journal of Honai Math, Vol. 3, No. 2, pp. 181-196, Oktober 2020

Weluk, Leton, \& Lakapu, Pengembangan Bahan Ajar Matematika Berbasis Visual untuk Peserta Didik Tunarungu 